\title{
PENGARUH LINGKUNGAN KERJA DAN KEPUASAN KERJA TERHADAP KUALITAS PELAYANAN
}

\author{
Rizali Sofiyan ${ }^{1}$ \\ ${ }^{1}$ Program Studi Manajemen Pascasarjana Universitas Galuh Ciamis \\ e-mail: rizalysofyan@gmail.com
}

\author{
Article History : \\ Received 16 August 2018 \\ Recieved in revished form \\ 28 September 2018 \\ Acepted 15 October 2018 \\ Available offline 29 October 2018 \\ Available online 29 October 2018
}

Language Transcript :

Indonesia (id)

Key Words :

Lingkungan Kerja

Kepuasan Kerja

Kualitas Pelayanan

\begin{abstract}
Penelitian ini bertujuan untuk mengetahuipengaruh lingkungan kerja dan kepuasan kerja terhadap kualitas pelayanan pada RSUD Kabupaten Ciamis. Metode yang dilakukan adalah metode deskriptif kuantitatif. Hasil penelitian menunjukan bahwa : Indikator hubungan antar bawahan dengan pimpinan sangat besar pengaruhnya terhadap variabel lingkungan kerja. Berdasarkan uji statistik bahwa lingkungan kerja berpengaruh positif dan signifikan terhadap kualitas pelayanan. Jika lingkungan kerja ditingkatkan maka kualitas pelayanan akan meningkat. Dengan demikian maka hipotesis pertama teruji kebenarannya. indikatorpegawai merasa puas jika komponen watak/genetik dapat dianalisis sangat besar pengaruhnya terhadap variabel kepuasan kerja. Berdasarkan uji statistik bahwa kepuasan kerja berpengaruh positif dan signifikan terhadap kualitas pelayanan. Jika kepuasan kerja ditingkatkan maka kualitas pelayanan akan meningkat. Dengan demikian maka hipotesis kedua teruji kebenarannya.indikator memberikan perhatian yang tulus dan bersifat individual atau pribadi (Empathy) besar pengaruhnya terhadap variabel kepuasan kerja. Berdasarkan uji statistik bahwa lingkungan kerja dan kepuasan kerja berpengaruh positif dan signifikan terhadap kualitas pelayanan. Jika lingkungan kerja dan kepuasan kerja ditingkatkan maka kualitas pelayanan akan meningkat. Dengan demikian maka hipotesis ketiga teruji kebenarannya.
\end{abstract}

\section{PENDAHULUAN}

Di tengah krisis multidimensi yang melanda tanah air kita, terdapat banyak masalah terjadi yang membuat rakyat Indonesia kebingungan untuk memajukan bangsa ini. Satu per satu masalah muncul di negeri ini, mulai dari bencana alam sampai penyebaran wabah penyakit. Isu yang paling mengancam nasib bangsa ini adalah masalah kesehatan nasional. Masalah kesehatan nasional yang dihadapi bangsa kita sekarang adalah pelayanan kesehatan yang buruk, serta kurangnya biaya pengadaan fasilitas kesehatan padahal kesehatan nasional merupakan fondasi penting dalam memajukan bangsa ini dari keterpurukan. Pertanyaan dalam hal tersebut adalah apakah sistem pelayanan kesehatan Indonesia sudah memadai dalam menangani masalah kesehatan Indonesia?

Salah satu permasalahan yang terjadi adalah pelayanan kesehatan di rumah sakit. Kualitas pelayanan rumah sakit dapat diketahui dari penampilan professional personil rumah sakit, efisiensi dan efektivitas pelayanan serta kepuasan pasien. Kepuasan pasien ditentukan oleh keseluruhan pelayanan: pelayanan admisi, 
dokter, perawat, makanan, obat-obatan, sarana dan peralatan, fasilitas dan lingkungan fisik rumah sakit.

Dalam pengalaman sehari-hari, ketidakpuasan pasien yang paling sering dikemukakan dalam kaitannya dengan sikap dan perilaku petugas RS, antara lain: keterlambatan pelayanan dokter dan perawat, dokter sulit ditemui, dokter yang kurang komunikatif dan informatif, lamanya proses masuk rawat, aspek pelayanan di RS, serta ketertiban dan kebersihan lingkungan RS. Perilaku, tutur kata, keacuhan, keramahan petugas, serta kemudahan mendapatkan informasi dan komunikasi menduduki peringkat yang tinggi dalam persepsi kepuasan pasien RS. Tidak jarang walaupun pasien/keluarganya merasa outcome tak sesuai dengan harapannya merasa cukup puas karena dilayani dengan sikap yang menghargai perasaan dan martabatnya.

Dalam memberikan pelayanannya rumah sakit harus cepat tanggap terhadap kebutuhan pasien baik itu dari segi pengobatan, administrasi maupun ketepatan dalam bertindak. Tidak semua rumah sakit akan kita dapatkan kualitas pelayanan yang maksimal untuk pasiennya. Kualitas pelayanan kesehatan adalah:Penampilan yang pantas dan sesuai (yang berhubungan dengan standar-standar) dari suatu intervensi yang diketahui aman, yang dapat memberikan hasil kepada masyarakat yang bersangkutan dan yang telah mempunyai kemampuan untuk menghasilkan dampak pada kematian, kesakitan, ketidakmampuan dan kekurangan gizi (Milton I Roemer dan CMontoya Aguilar, WHO, 1988).

Permasalahan yang sering kita temukan dalam pelayanan di rumah sakit diantarannya adalah terjadi perbedaan pelayanan yang diberikan kepada pasien yang menggunakan askeskin dengan pasien yang membayar langsung ke rumah sakit. Ini membuktikkan bahwa rumah sakit tersebut tidak sepenuhnya memberikan pelayanan yang sesuai dengan dimensi mutu yaitu Empaty (empati); meliputi pemahaman pemberian perhatian secara individual kepada pelanggan, kemudahan dalam melakukan komunikasi yang baik, dan memahami kebutuhan pelanggan tanpa membeda-bedakan pelanggan/pasien.

Jika kita tinjau kembali dari dimensi mutu, rumah sakit tersebut dikatakan bermutu jika sudah mencakup ke sepuluh dimensi mutu yang digunakannya yaitu nyata dan berwujud, keandalan dari rumah sakit ketanggapan petugas dalam memberikan pelayanan, kompetensi para petugas kesehatannya yang baik, kemudahan dalam memberikan akses pelayanan, keramahtamahan dan komunikasi yang digunakan dalam memberi pelayanan, dan juga apakah rumah sakit ini mampu memberikan kepercayaan pada setiap pelanggannya, yang tidak kalah pentingnya adalah pihak rumah sakit mampu memberikan keamanan bagi pasienpasiennya sehingga dengan demikian terwujudlah kepuasan pasien terhadap pelayanan rumah sakit tersebut.

Pelayanan pasien di RS tidak hanya dilakukan oleh sekelompok dokter (medis) saja, tapi juga pelayanan dari bagian paramedik (perawat), penunjang medis, dan non medis. Pada prinsipnya, semua unsurunsur tersebut wajib bekerjasama serta adanya koordinasi diantara sesama mereka untuk mencapai pelayanan yang optimal. Sebagai contoh pelayanan dalam hal keperawatan yang sangat mendasar adalah adanya sikap yang ramah dan komunikatif terhadap pasien dan keluarga pasien. Dengan adanya pelayanan yang lemah lembut dan ramah merupakan salah satu obat dalam kesembuhan pasien secara psikologis.

Hal utama yang perlu diperhatikan dalam peningkatan mutu di sebuah rumah sakit adalah manajemen rumah sakit harus bertindak secepatnya untuk segera meningkatkan kualitasnya, baik sarana 
maupun prasarana, pelayanan terhadap pasien serta meningkatkan kualitas tenaga medisnya. Sehingga dengan ini akan terciptanya kepuasaan pelanggan/ pasien terhadap pelayanan yang diberikan oleh rumah sakit tersebut.

Lingkungan adalah keseluruhan atau setiap aspek dan gejala fisik dan sosial kultural yang mempengaruhi individu. Kerja adalah aktifitas manusia baik fisik maupun mental yang didasarkan adalah bawaan dan mempunyai tujuan yaitu mendapatkan kepuasan (As'ad, 1991:47). Dengan demikian dapat disimpulkan bahwa lingkungan kerja adalah segala sesuatu yang ada disekitar para pekerjaan dan yang dapat mempengaruhi dirinya dalam menjalankan tugas-tugas yang dibebankan (Nitisemito 1982:183).

Hasil pengamatan awal menunjukkan bahwa lingkungan kerja yang kurang menunjang menyebabkan rendahnya kualitas pelayanan. Seperti tata letak ruangan yang sangat besar, menyebabkan proses pelayanan memakan waktu, karena harus berjalan dari ujung ke ujung. Selain itu pemakaian warna dalam masing-masing ruangan memberikan kesan kurang bersemangat, sehingga sangat memungkinkan berpengaruh terhadap kualitas pelayanan.

Begitu juga dengan kepuasan kerja, dimana banyak pegawai yang belum merasa puas dengan pekerjaan yang selama ini di kerjakannya. Menurut Siagian (1998:126) mengemukakan bahwa kepuasan kerja adalah sikap umum seseorang karyawan terhadap pekerjaannya, artinya secara umum dapat dirumuskan bahwa seorang yang memiliki rasa puas terhadap pekerjaannya akan mempunyai sikap positif terhadap organisasi dimana dia bekerja. Sebaliknya orang yang merasa tidak puas dengan pekerjaannya apapun faktor yang menyebabkan ketidakpuasan itu, misalnya gaji yang rendah, pekerjaan yang membosankan, kondisi kerja yang kurang memuaskan, maka akan cenderung bersikap negatif terhadap organisasi tempat dia bekerja.

Pendapat di atas menunjukkan bahwa apabila pegawai merasa puas, maka akan memberikan dampak pada pekerjaannya. pegawai akan dapat bekerja dengan baik dan mampu menciptakan kualitas pelayanan akan terwujud.

\section{METODOLOGI}

Metode penelitian yang akan digunakan dalam penyusunan tesis ini adalah deskriptifdan verifikatif. Penelitian deskriptif adalah suatu metode yang menggambarkan apa yang dilakukan berdasarkan fakta-fakta atau kejadiankejadian pada objek yang diteliti, untuk kemudian diolah menjadi suatu data dan selanjutnya akan dilakukan suatu analisis sehingga pada akhirnya dihasilkan suatu kesimpulan. Sedangkan penelitian verifikatif adalah suatu metode yang dilakukan untuk menguji hipotesis dengan menggunakan perhitungan dari statistik.

Mengingat sifat penelitian ini adalah deskriftif dan verifikatif yang dilaksanakan melalui pengumpulan data di lapangan, maka metode penelitian yang digunakan adalah metode deskrtiptif survey dan explanatory survey. Tipe penyelidikan yang dilakukan adalah causalitas karena menerangkan suatu pengaruh dari satu variabel terhadap variabel lainnya.

Penelitian ini menggunakan desain penelitian menurut tingkat eksplanasi karena menjelaskan hubungan kausal antara variabel-variabel melalui pengujian hipotesis. Hal ini sesuai dengan pendapat Singarimbun dan Effendi (1989 : 5) bahwa apabila peneliti menjelaskan hubungan kausal antara variabel-variabel melalui pengujian hipotesis, maka dinamakan penelitian penjelasan atau explanatory 
research. Di mana menurut pendapat Sugiyono (2001 : 6) adalah enelitian menurut tingkat eksplanasi adalah tingkat penjelasan bagaimana variabel-variabel yang diteliti itu akan menjelaskan objek yang diteliti melalui data yang terkumpul.

Menurut pendapat Sugiyono (2005 : 43) paradigma penelitian dapat diartikan sebagai pola pikir yang menunjukan hubungan antara variabel yang akan diteliti yang sekaligus mencerminkan jenis dan jumlah rumusan masalah yang perlu dijawab melalui penelitian, teori yang digunakanuntuk merumuskan hipotesis, jenis dan jumlah hipotesis dan teknik analisis statistik yang akan digunakan.

\section{HASIL DAN PEMBAHASAN}

\section{1 Pengaruh lingkungan kerja terhadap kualitas pelayanan pada RSUD Kabupaten Ciamis}

Berdasarkan hasil penelitian diketahui bahwa hasil jawaban responden menunjukkan indikator hubungan antar bawahan dengan pimpinan paling dominan mempengaruhi variabel lingkungan kerja. Artinya bahwa indikator hubungan antar bawahan dengan pimpinan sangat besar pengaruhnya terhadap variabel lingkungan kerja.

Berdasarkan uji statistik bahwa lingkungan kerja berpengaruh positif dan signifikan terhadap kualitas pelayanan. Jika lingkungan kerja ditingkatkan maka kualitas pelayanan akan meningkat. Dengan demikian maka hipotesis pertama teruji kebenarannya.

Hasil di atas sejalan dengan pendapat Sedarmayanti (2001 : 1) dalam jurnal Ahmad Nur Susilo (2008) bahwa Lingkungan kerja adalah keseluruhan alat perkakas dan bahan yang dihadapi lingkungan sekitarnya dimana seseorang bekerja, metode kerjanya, serta pengaturan kerjanya baik sebagai perorangan maupun sebagai kelompok.

Lingkungan adalah keseluruhan atau setiap aspek dan gejala fisik dan sosial kultural yang mempengaruhi individu. Kerja adalah aktifitas manusia baik fisik maupun mental yang didasarkan adalah bawaan dan mempunyai tujuan yaitu mendapatkan kepuasan (As'ad, 2011:47). Dengan demikian dapat disimpulkan bahwa lingkungan kerja adalah segala sesuatu yang ada disekitar para pekerjaan dan yang dapat mempengaruhi dirinya dalam menjalankan tugas-tugas yang dibebankan (Nitisemito 2005:183).

Menurut Mardiana (2005: 15) berpendapat lingkungan kerja adalah lingkungan dimana pegawai melakukan pekerjaannya seharihari. Lingkungan kerja yang kondusif memberikan rasa aman dan memungkinkan para pegawai untuk dapat berkerja optimal. Lingkungan kerja dapat mempengaruhi emosi pegawai. Jika pegawai menyenangi lingkungan kerja dimana dia bekerja, maka pegawai tersebut akan betah di tempat kerjanya untuk melakukan aktivitas sehingga waktu kerja dipergunakan secara efektif dan optimis prestasi kerja pegawai juga tinggi. Lingkungan kerja tersebut mencakup hubungan kerja yang terbentuk antara sesama pegawai dan hubungan kerja antar bawahan dan atasan serta lingkungan fisik tempat pegawai bekerja.

Berdasarkan uraian teoritis lingkungan kerja sebagaimana disebut di atas,maka peneliti mengambil kesimpulan bahwa faktor-faktor yang mempengaruhi lingkungan kerja adalah Perlengakapan dan fasilitas, suasana kerja (lingkungan non fisik), lingkungan tempat kerja (lingkungan fisik).

\section{1) Perlengkapan dan Fasilitas}

Fasilitas menurut Moenir (1983; 197) adalah segala sesuatu yang ditempati dan dinikmati oleh pegawai baik dalam hubungan langsung maupun tidak langsung. 
Dari pengertian di atas yang dimaksud fasilitas di atas adalah :

- Fasilitas alat kerja yaitu semua benda yang berfungsi langsung digunakan dalam melaksanakan pekerjaannya.

- Fasilitas perlengkapan yaitu merupakan semua benda atau barang yang digunakan dalam pekerjaan, tetapi tidak langsung digunakan untuk menyelesaikan pekerjaan melainkan berfungsi sebagai pelancar dalam pekerjaan.

- Fasilitas sosial yaitu merupakan suatu fasilitas yang digunakan oleh pegawai dan berfungsi sosial, misalnya dapat berupa penyediaan mess, asrama untuk pegawai yang belum menikah.

\section{2) Suasana Kerja (Nonphysical Working Environment)}

Terdapat ungkapan atau pernyataan bahwa organisasi adalah kumpulan orang-orang, hal ini adalah suatu ungkapan yang biasa namun meskipun demikiahnh hal ini menitik beratkan pada pentingnya orangorang dalam pekrjaan pengorganisasian. Hal inilah yang menimbulkan ide pokok bahwa orang-orang membentuk pusat dimana keluar konsep-konsep organisasi tentang pekerjaan yang harus dilakukan, otoritas dan lingkungan kerja (Moekijat, 1995: 223)

Dengan adanya suatu lingkungan kerja yang baik dan menyenangkan maka pegawai akan bersemangat dalam melaksanakan pekerjaannya. Suasana kerja dapat mendukung tumbuhnya semangat kerja pegawai dan sangat mempengaruhi pula bagi tercapainya tujuan organisasi. Suasana kerja yang baik dapat tercipta dengan adanya penyusunan organisasi, karena ini merupakan suatu alat yang memberikan pengelompokan kegiatankegiatan khusus dan mengelompokkan orang-orang dan menerapkan tujuan manajemen. Dengan penyusunan oraganisasi yang baik dan pembagian tugas yang jelas dapat menciptakan suasana kerja yang sehat sehingga dapat menumbuhkan semangat kerja pegawai.

Nawawi dan Martini (1985; 129) mengemukakan bahwa faktor non fisik dalam lingkungan kerja adalah penghargaan, penghormatan, pengakuan dan perlakuan yang wajar serta bersifat manusiawi, toleransi, solidaritas, dan tanggung jawab.

Dari beberapa pokok-pokok di atas dapat dijelaskan bahwa, pegawai juga memerlukan adanya suatu penghargaan yang sifatnya nonfinansial baik dari pimpinan maupun dari rekan kerja, seperti pujian, pengakuan atas prestasi yang dicapainya, hal ini akan mendorong pegawai untuk lebih giat dalam melaksanakan pekerjaan. Selain itu perlakuan yang wajar tanpa adanya tekanan-tekanan atau diskriminasi sangat dibutuhkan bagi para pegawai. Dengan demikian akan tercipta suatu suasana kerja yang menyenangkan. Struktur organisasi yang tepat, terdapat kerjasama antar pegawai tanpa adanya diskriminasi, hal ini akan mempengaruhi pegawai untuk lebih bertanggung jawab dalam melaksanakan tugas mereka.

\section{3) Lingkungan Tempat Kerja (Physical Working Environment)}

Lingkungan tempat kerja (physical working environment) meliputi (1) pewarnaan; (2) kebersihan; (3) udara; (4) penerangan; dan (5) keamanan.

\section{2 Pengaruh Kepuasan Kerja terhadap kualitas pelayanan pada RSUD Kabupaten Ciamis}

Berdasarkan hasil penelitian diketahui bahwa hasil jawaban responden menunjukkan indikator pegawai merasa puas jika komponen watak/genetic dapat dianalisis paling dominan mempengaruhi variabel kepuasan kerja. Artinya bahwa 
indikatorpegawai merasa puas jika komponen watak/genetic dapat dianalisis sangat besar pengaruhnya terhadap variabel kepuasan kerja. Berdasarkan uji statistik bahwa kepuasan kerja berpengaruh positif dan signifikan terhadap kualitas pelayanan. Jika kepuasan kerja ditingkatkan maka kualitas pelayanan akan meningkat. Dengan demikian maka hipotesis kedua teruji kebenarannya.

Hasil penelitian di atas sejalan dengan pendapat Rivai (2004:475) mengungkapkan "kepuasan kerja merupakan evaluasi yang menggambarkan seseorang atas perasaan sikapnya senang atau tidak puas dalam bekerja”. Sedangkan Siagian (1998:126) mengemukakan bahwa: Kepuasan kerja adalah sikap umum seseorang karyawan terhadap pekerjaannya, artinya secara umum dapat dirumuskan bahwa seorang yang memiliki rasa puas terhadap pekerjaannya akan mempunyai sikap positif terhadap organisasi dimana dia bekerja. Sebaliknya orang yang merasa tidak puas dengan pekerjaannya apapun faktor yang menyebabkan ketidakpuasan itu, misalnya gaji yang rendah, pekerjaan yang membosankan, kondisi kerja yang kurang memuaskan, maka akan cenderung bersikap negatif terhadap organisasi tempat dia bekerja.

Kepuasan kerja menurut Susilo Martoyo (1992 : 115), pada dasarnya merupakan salah satu aspek psikologis yang mencerminkan perasaan seseorang terhadap pekerjaannya, ia akan merasa puas dengan adanya kesesuaian antara kemampuan, keterampilan dan harapannya dengan pekerjaan yang ia hadapi.

Keith Davis (dalam Mangkunegara, 2005) mengartikan kepuasan kerja adalah perasaan menyokong atau tidak menyokong yang dialami pegawai dalam bekerja. Pendapat lain dari Wexley dan Yuki (dalam Mangkunegara, 2005) mengartikan kepuasan kerja adalah cara pegawai merasakan dirinya atau pekerjaannya.
Kepuasan kerja adalah sikap umum yang merupakan hasil dari beberapa sikap khusus terhadap faktor-faktor pekerjaan, penyesuaian diri, dan hubungan sosial individu di luar kerja (dalam Mangkunegara, 2005). Selain itu menurut Hawell dan Dipboye (dalam Munandar, 2004) memandang kepuasan kerja sebagai hasil keseluruhan dari derajat rasa suka atau tidak sukanya tenaga kerja terhadap beberapa aspek dari pekerjaannya. Dengan kata lain, kepuasan kerja mencerminkan sikap tenaga kerja terhadap pekerjaannya.

Adapun faktor penentu kepuasan kerja adalah sebagai berikut:

a. Faktor-faktor yang biasanya digunakan untuk mengukur kepuasan kerja seorang karyawan menurut Rivai (2009:860) adalah: (1) Isi pekerjaan, penampilan tugas pekerjaan yang aktual dan sebagai kontrol terhadap pekerjaan; (2) Supervisi; (3) Organisasi dan manajemen; (4) Kesempatan untuk maju; 5) Gaji dan keuntungan dalam bidang finansial seperti adanya insentif ; (6) Rekan kerja; (7) Kondisi pekerjaan.

b. Faustino Cardoso Gomes (1999;178), membuat suatu kesimpulan menyeluruh tentang kepuasan kerja pegawai dengan pertimbangan-pertimbangan subjektif berhubungan dengan: (1) Gaji, (2) Keselamatan kerja, (3) Supervisi, (4) Relasi-relasi antar perorangan dalam kerja, peluang-peluang dimasa yang akan datang, (5) Pekerjaan itu sendiri.

c. Alternatif dari konsep kepuasan kerja satu dimensi adalah konse focet (permukaan) atau komponen yang menganggap bahwa kepuasan karyawan dengan berbagai aspek situasi pekerjaan yang berbeda dapat bervariasi secara bebas dan harus diukur secara terpisah. Diantara konsep focet yang mungkin diperiksa adalah (1) Beban kerja, (2) Keamanan kerja, (3) Kompensasi, (4) Kondisi kerja, (5) Status dan prestise 
kerja, (6) Kecocokan rekan kerja, (7)

Kebijakan penilaian perusahaan, (8)

Praktek manajemen umum, (9)

Hubungan antara atasan dan bawahan, (10) Otonomi dan tanggung jawab jabatan, (11) Kesempatan untuk mempergunakan pengetahuan dan keterampilan, (12) Kesempatan untuk pertumbuhan dan pengembangan (L.N. Jewell dan Marc Siegal 1998).

d. Job Descriptive Index (JDI) dalam Rivai (2009:860), faktor penyebab kepuasan kerja ialah: (1) Bekerja pada tempat yang tepat, (2) Pembayaran yang sesuai, (3) Organisasi dan manajemen, (4) Supervisi pada pekerjaan yang tepat, (5) Orang yang berada dalam pekerjaan yang tepat.

e. Siagian (1986:25) menyatakan, bahwa harapan-harapan pada organisasi, biasanya tercermin antara lain : (1) Kondisi kerja yang baik; (2) Merasa diikutsertakan dalam proses pengambilan keputusan, terutama yang menyangkut nasibnya; (3) Cara pendisiplinan yang diplomatik; (4) Penghargaan yang wajar atas prestasi kerja; (5) Kesetiaan pimpinan terhadap bawahannya; (6) Pembayaran yang adil dan wajar; (7) Kesempatan promosi dan berkembang dalam organisasi; (8) Adanya pengertian pimpinan jika bawahan menghadapi masalah pribadi; (9) Jaminan adanya perlakuan yang adil dan objektif; (10) Pekerjaan yang menarik.

Berdasarkan berbagai pendapat di atas menurut As'ad (1999:35) dapat dirangkum mengenai faktor-faktor yang menimbulkan kepuasan kerja, yaitu:

a. Faktor psikologi, merupakan faktor yang berhubungan dengan kejiwaan karyawan, yang meliputi: minat; ketentraman dalam bekerja, sikap terhadap kerja, bakat, dan keterampilan b. Faktor Sosial, merupakan faktor yang berhubungan dengan interaksi sosial, baik antara sesama karyawan, dengan atasannya maupun karyawan yang berbeda jenis pekerjaannya.

c. Faktor fisik, merupakan faktor yang berhubungan dengan kondisi fisik lingkungan kerja dan kondisi fisik karyawan, meliputi jenis pekerjaan, pengaturan waktu kerja dan istirahat, perlengkapan kerja, keadaan ruangan, suhu udara, penerangan, pertukaran udara, kondisi kesehatan karyawan, umur dan sebagainya.

d. Faktor finansial, merupakan faktor yang berhubungan dengan jaminan serta kesejahteraan karyawan, yang meliputi sistem dan besarnya gaji atau upah, jaminan sosial, macam-macam tunjangan, fasilitas yang diberikan, promosi dan sebagainya.

\section{3 Pengaruh Lingkungan Kerja dan Kepuasan Kerja terhadap kualitas pelayanan pada RSUD Kabupaten Ciamis}

Berdasarkan hasil penelitian diketahui bahwa hasil jawaban responden menunjukkan indikator memberikan perhatian yang tulus dan bersifat individual atau pribadi(Empathy) paling dominan mempengaruhi variabel kualitas pelayanan. Artinya bahwa indikator memberikan perhatian yang tulus dan bersifat individual atau pribadi(Empathy) besar pengaruhnya terhadap variabel kepuasan kerja. Berdasarkan uji statistik bahwa lingkungan kerja dan kepuasan kerja berpengaruh positif dan signifikan terhadap kualitas pelayanan. Jika lingkungan kerja dan kepuasan kerja ditingkatkan maka kualitas pelayanan akan meningkat. Dengan demikian maka hipotesis ketiga teruji kebenarannya.

Hasil di atas sejalan dengan pendapat Tjiptono, 2004:59 yaitu sebagai berikut: Kualitas pelayanan adalah tingkat 
keunggulan yang diharapkan dan pengendalian atas tingkat keunggulan tersebut untuk memenuhi keinginan pelanggan. Apabila jasa atau pelayanan yang diterima atau dirasakan (perceived service) sesuai dengan yang diharapkan, maka kualitas jasa atau pelayanan dipersepsikan baik dan memuaskan. Jika jasa atau pelayanan yang diterima melampaui harapan pelanggan, maka kualitas jasa atau pelayanan dipersepsikan sebagai kualitas yang ideal. Sebaliknya jika jasa atau pelayanan yang diterima lebih rendah daripada yang diharapkan, maka kualitas jasa atau pelayanan dipersepsikan buruk.

Berdasarkan penjelasan yang dipaparkan di atas, maka dapat diindikasikan bahwa sebuah kualitas pelayanan yang diharapkan oleh masyarakat sebagai penerima layanan mengharapkan tingkat keunggulan dari setiap jasa pelayanan yang didapat dari pelayanan yang didapatkan sebelumnya. Bila pelayanan yang diberikan melampaui harapan dari masyarakat pelanggan maka kualitas pelayanan yang diberikan akan mendapatkan persepsi yang ideal dari para penerima pelayanan.

Menurut Parasuraman, Zeithamal \& Bery (Rangkuti, 2002: 29), bahwa untuk dapat menentukan standar kualitas jasa dapat dilihat dari dimensi atau kriteria berikut:
a. Keandalan(Reliability)
b. Ketanggapan(Responsiveness)
c. Kemampuan(Competence)
d. Mudah diperoleh(Access)
e. Keramahan(Courtesy)
f. Komunikasi(Communication)
g. Dapat dipercaya(Credibility)
h. Keamanan(Security)
i. memahami pelanggan(Understandingknowing the costumer),

j. bukti nyata yang kasat mata(Tangibles).

Selanjutnya Parasuraman, Zeithamal \& Bery (Rangkuti, 2002: 29) mengkonversi kesepuluh dimensi kualitas jasa ke dalam lima dimensi sebagai berikut:

a. kehandalan (Reliability) adalah kemampuan untuk memberikan pelayanan yang dijanjikan dengan tepat (accurately) dan kemampuan untuk dipercaya (dependably), terutama memberikan jasa secara tepat waktu (ontime), dengan cara yang sama sesuai dengan jadwal yang telah dijanjikan dan tanpa melakukan kesalahan setiap kali.

b. daya tanggap (Responsiveness) adalah kemauan atau keinginan para karyawan untuk membantu dan memberikan jasa yang dibutuhkan konsumen. Membiarkan konsumen menunggu, terutama tanpa alasan yang jelas, akan menimbulkan kesan negatif yang tidak seharusnnya terjadi. Kecuali jika kesalahaan ini ditanggapi dengan cepat, maka bisa menjadi suatu yang berkesan dan menjadi pengalaman yang menyenangkan.

c. jaminan (Assurance) meliputi pengetahuan, kemampuan, keramahan, sopan, dan sifat dapat dipercaya dari kontak personil untuk menghilangkan sifat keragu-raguan konsumen dan merasa terbebas dari bahaya dan resiko.

d. Empati (Emphaty Meliputi sikap kontak personil maupun perusahaan untuk memahami kebutuhan maupun kesulitan konsumen, komunikasi yang baik, perhatian pribadi, kemudahan dalam melakukan komunikasi atau hubungan.

e. Produk-produk fisik (Tangibles). Tersediannya fasilitas fisik, perlengkapan, dan sarana komunikasi serta yang lainnya yang dapat dan harus ada dalam proses jasa. 


\section{SIMPULAN}

Berdasarkan hasil penelitian dan pembahasan, maka penulis menarik kesimpulan hasil penelitian sebagai berikut.

1. Berdasarkan hasil penelitian diketahui bahwa hasil jawaban responden menunjukkan indikator hubungan antar bawahan dengan pimpinan paling dominan mempengaruhi variabel lingkungan kerja. Artinya bahwa indikator hubungan antar bawahan dengan pimpinan sangat besar pengaruhnya terhadap variabel lingkungan kerja. Berdasarkan uji statistik bahwa lingkungan kerja berpengaruh positif dan signifikan terhadap kualitas pelayanan. Jika lingkungan kerja ditingkatkan maka kualitas pelayanan akan meningkat. Dengan demikian maka hipotesis pertama teruji kebenarannya.

2. Berdasarkan hasil penelitian diketahui bahwa hasil jawaban responden menunjukkanindikator pegawai merasa puas jika komponen watak/genetik dapat dianalisis paling dominan mempengaruhi variabel kepuasan kerja. Artinya bahwa indikatorpegawai merasa puas jika komponen watak/genetik dapat dianalisis sangat besar pengaruhnya terhadap variabel kepuasan kerja. Berdasarkan uji statistik bahwa kepuasan kerja berpengaruh positif dan signifikan terhadap kualitas pelayanan. Jika kepuasan kerja ditingkatkan maka kualitas pelayanan akan meningkat. Dengan demikian maka hipotesis kedua teruji kebenarannya.

3. Berdasarkan hasil penelitian diketahui bahwa hasil jawaban responden menunjukkan indikator memberikan perhatian yang tulus dan bersifat individual atau pribadi(Empathy) paling dominan mempengaruhi variabel kualitas pelayanan. Artinya bahwa indikator memberikan perhatian yang tulus dan bersifat individual atau pribadi(Empathy) besar pengaruhnya terhadap variabel kepuasan kerja. Berdasarkan uji statistik bahwa lingkungan kerja dan kepuasan kerja berpengaruh positif dan signifikan terhadap kualitas pelayanan. Jika lingkungan kerja dan kepuasan kerja ditingkatkan maka kualitas pelayanan akan meningkat. Dengan demikian maka hipotesis ketiga teruji kebenarannya.

\section{DAFTAR PUSTAKA}

As'ad, 1999,Seri Ilmu Sumber Daya Manusia: Psikologi Industri. Yogyakarta: Liberti Yogyakarta.

Mardiana.2005. Manajemen Produksi. PenerbitBadanPenerbit IPWI, Jakarta.

Moekijat, D. 1995. Kepemimpinan dan Motivasi. Ghalia, Jakarta.

Moenir, A. S. 1983. Pendekatan manusiawi dan organisasi terhadap pembinaan kepegawaian. Gunung Agung.

Nawawi, Hadari. 2001. Manajemen Strategik. Yogyakarta: Gajah Mada. University Press.

Nitisemito, A. S. 2005. Manajemen personalia (manajemen sumber daya manusia), edisi kelima, cetakan keempat belas. Jakarta: Ghalia Indonesia.

Parasuraman, dkk. 1985. Marketing Services: Competing Through Quality. New York: The Free Press.

Rangkuti, Freddy. 2002. Analisis SWOT Teknik Membedah Kasus Bisnis Reorientasi Konsep Perencanaan Strategis Untuk Mnghadapi Abad 21. Jakarta: PT. Gramedia Pustaka Utama

Rivai, Veithzal (2009) . Kepemimpinan dan Perilaku Organisasi. Jakarta: PT Raja Grafindo Persada. 
Roemer, M. I., Montoya-Aguilar, C., \& World Health Organization. 1988.

Quality assessment and assurance in primary health care.

Sugiyono. 2008 Metode Penelitian Bisnis. Bandung: CV. Alfabeta.

Tjiptono, Fandy. 2001. Prinsip dan Dinamika Pemasaran. Yogyakarta: J\&J Learning.

, Undang-Undang Nomor 12 tahun 1985 yang diubah menjadi UU No. 12 tahun 1994 tentang Pajak Bumi dan Bangunan

, Undang-Undang Nomor 28 Tahun 2009 tentang Pajak Daerah dan Retribusi Daerah 